\title{
Role of serum LDH in preeclampsia as a prognostic factor - a cross sectional case control study in tertiary care hospital
}

\author{
Vinitha Padmini Mary ${ }^{1 *}$, M. Chellatamizh¹, S. Padmanaban²
}

\begin{abstract}
${ }^{1}$ Department of Obstetrics and Gynecology, Government Kilpauk Medical College, Chennai, Tamilnadu, India
${ }^{2}$ Scientist, NIRRH Field unit, ICMR, KMC Hospital, Chennai-10, Tamilnadu, India
\end{abstract}

Received: 01 December 2016

Accepted: 26 December 2016

\section{*Correspondence:}

Dr. Vinitha Padmini Mary,

E-mail: dr.vinitha_mmc@yahoo.com

Copyright: ( $)$ the author(s), publisher and licensee Medip Academy. This is an open-access article distributed under the terms of the Creative Commons Attribution Non-Commercial License, which permits unrestricted non-commercial use, distribution, and reproduction in any medium, provided the original work is properly cited.

\section{ABSTRACT}

Background: LDH is an intracellular cytoplasmic enzyme. It is ubiquitous to all the major organ systems. Cellular enzymes in extracellular space have no metabolic function, although they serve as indicators of disturbances in cellular integrity. Serum LDH is abnormal in many disorders, therefore total serum LDH is highly sensitive but nonspecific test. In preeclampsia also LDH may be elevated and can indicate the prognosis for both mother and fetus. We conducted this study to examine the relationship between lactate dehydrogenase concentration and the severity of the disease and the occurrence of its complications.

Methods: 200 pre-eclamptic women (121 with mild and 79 with severe pre-eclampsia) and 200 healthy normotensive controls were studied prospectively at Government Kilpauk medical college and hospital between January and December 2015. Demographic, hemodynamic, and laboratory data were compared among the three groups. The symptoms and complications of severe pre-eclampsia along with fetal outcome were analyzed according to the levels of LDH.

Results: Severely pre-eclamptic patients were significantly younger, with low gravidity and parity. On the other hand, they had significantly increased systolic and diastolic pressure and liver enzymes, uric acid, urine albumin, and LDH levels. The symptoms and complications of pre-eclampsia along with perinatal mortality were increased significantly in patients with LDH >800 IU/l compared with those who had lower levels.

Conclusions: Lactate dehydrogenase is a useful biochemical marker that reflects the severity of pre-eclampsia. In our study, LDH has been evaluated as a biochemical marker for preeclampsia and as a prognosticator of the disease severity. Detection of high-risk patients with increased levels of LDH mandate close monitoring and management to prevent maternal and fetal morbidity and mortality.

Keywords: Biomarker, Maternal morbidity, Maternal mortality, Severe preeclampsia, Serum LDH

\section{INTRODUCTION}

Pre-eclampsia is a pregnancy-specific condition that is characterized by hypertension and proteinuria occurring after 20 weeks of gestation. It complicates 5-8\% of all pregnancies'. Although the precise etiology of preeclampsia is not clear, defective placentation and endothelial dysfunction are considered the core features of pre-eclampsia'. ${ }^{3-5}$ Mild pre-eclampsia was defined as onset of hypertension after 20 weeks of gestation with diastolic blood pressure $>90$ and $\leq 110 \mathrm{mmHg}$ with or without proteinuria. When DBP $>110 \mathrm{mmHg}$ was measured on two occasions 6 hours apart with significant proteinuria $(>500 \mathrm{mg} / 24 \mathrm{~h})$, pre-eclampsia was considered severe.

Various causes that lead to these abnormalities have been proposed. These include immunological, genetic, and 
dietary causes, race, increased oxidative stress, and prostaglandin imbalance'. ${ }^{6,7}$ It carries substantial risks for both fetus and mother with a subsequent increase in the perinatal and maternal morbidity and mortality'. ${ }^{1,2}$

For established disease with involvement of various systems, several markers have been proposed, like markers for renal and liver function - urea, creatinine, uric acid, aspartate, and alanine transaminases, vascular function (prostacyclin, thromboxane, fibronectin, homocystine, nitric acid, cytokines), coagulation and fi brinolytic systems (tissue plasminogen activators, platelets, fibrinogen, antithrombin III, Von Willebrand factor), oxidative stress and lipids (lipid peroxides, antioxidants, lipoproteins), and placental function (human chorionic gonadotropin, corticotrophin releasing hormone, placental growth factor, a-fetoprotein, inhibin, activin, and uteroplacental fl ow (velocity wave form)'.5-7

Lactic dehydrogenase (LDH) is an intracellular enzyme that converts lactic acid to pyruvic acid, and elevated levels indicate cellular death and leakage of the enzyme from the cell. High levels of LDH were found in association with severe pre-eclampsia in a limited number of studies' ${ }^{8-10}$ As severe pre-eclampsia may lead to a numerous multisystem complications, we hypothesize that elevated levels of LDH may reflect the severity of pre-eclampsia and the occurrence of complications.

The aim of the study was to compare serum LDH levels in the normal pregnant women and in women with preeclampsia and eclampsia in antepartum period.

\section{METHODS}

A total of 200 pregnant women with pre-eclampsia (121 with mild and 79 with severe pre-eclampsia) and 200 healthy normotensive controls were studied prospectively at Government Kilpauk Medical College (KMC) between January and December 2015. The total number of deliveries during the same period was 5876 .

\section{Inclusion criteria}

- $\quad$ Singleton pregnancy

- Age 20 - 30 years,

- Preeclamptic women whose blood pressure was normal during first 20 weeks of gestation

- No previous history of hypertension 5 all the case were in the third trimester of pregnancy $(>28 \mathrm{wk}$ of gestation).

\section{Exclusion criteria}

Patients with diabetes, renal failure, haemolytic anemias, chronic hypertension, gestational diabetes, multiple pregnancy, smoking and alcoholism, liver disease, hepatotoxic drugs, stroke, coronary artery disease, chronic lung diseases, connective tissue disorders, disseminated intravascular coagulation and seizures, were excluded.

The patients were divided into three groups: group I $(n=200)$ - third-trimester healthy pregnant women, group II ( $\mathrm{n}=121)$ women with mild pre-eclampsia, and group III $(n=79)$ patients with severe pre-eclampsia. The three groups were matched according to age, gravidity, parity, maternal weight, and hemodynamic and laboratory results. Because levels of $\mathrm{LDH}<600 \mathrm{IU} / 1$ are common in normal pregnancy and only levels $>600$ IU/l were reported to be associated with complicated pre-eclampsia. After analysis of the results the women with severe preeclampsia (group III) were divided into 3 categories according to the level of lactic dehydrogenase-LDH $(<600,600-800$, and $>800 \mathrm{IU} / \mathrm{l})$ in order to identify the group with high risk of developing complications.

These patients were matched with respect to symptoms and complications of pre-eclampsia and pregnancyoutcome. Results expressed as means + SD was compared using one-way analysis of variance (ANOVA). Results expressed as percentages were compared using the chi-square test. Differences were considered significant when $\mathrm{p}<0.05$.

\section{RESULTS}

A statistically significant decrease is noted in age, gravidity and parity among women with severe preeclampsia compared with normotensive and those with mild pre-eclampsia $(\mathrm{p}<0.05)$.

Table 1: Demographic data of the three groups.

\begin{tabular}{|llll|}
\hline & $\begin{array}{l}\text { Normal } \\
\text { controls } \\
\text { N=200 }\end{array}$ & $\begin{array}{l}\text { Mild PE } \\
\text { N=121 }\end{array}$ & $\begin{array}{l}\text { Severe PE } \\
\text { N=79 }\end{array}$ \\
\hline Age (years) & $28.1 \pm 4.2$ & $27.3 \pm 3.9$ & $23.5 \pm 3.3^{*}$ \\
\hline Gravidity & $3.0 \pm 2.4$ & $2.7 \pm 1.5$ & $2.1 \pm 1.2^{*}$ \\
\hline Parity & $2.2 \pm 0.5$ & $1.4 \pm 0.5$ & $1.1 \pm 0.1^{*}$ \\
\hline $\begin{array}{l}\text { Maternal } \\
\text { weight }(\mathrm{kg})\end{array}$ & $57 \pm 4.7$ & $68.3 \pm 7.1$ & $72.4 \pm 6.4$ \\
\hline
\end{tabular}

Values are given as mean \pm SD $* p<0.05$.

Table 2 shows the hemodynamic and laboratory data of the three groups. In comparison with groups I and II, women with severe pre-eclampsia showed a statistically significant increase in terms of systolic and diastolic pressure $(\mathrm{p}<0.05)$, urine albumin $(\mathrm{p}<0.05)$, uric acid $(p<0.5)$, LDH $(p<0.0001)$ and liver enzymes $(p<0.05)$.

LDH levels $>600$ IU/l were seen in 47 of the $79(59.49 \%)$ with severe pre-eclampsia compared with $4.8 \%$ and $18.2 \%$ of the normotensive and mildly preeclamptic women. Abnormally elevated liver enzymes were seen in $48 \%$ of the severely pre-eclamptic patients. The frequency of symptoms and complications and pregnancy outcomes of severe pre-eclampsia according to LDH levels are shown in Tables 3-5. 
Table 2: Hemodynamics and laboratory data of the three groups.

\begin{tabular}{|c|c|c|c|}
\hline & $\begin{array}{l}\text { Normal } \\
\text { controls } \\
\mathrm{N}=200\end{array}$ & $\begin{array}{l}\text { Mild PE } \\
N=121\end{array}$ & $\begin{array}{l}\text { Severe PE } \\
\mathrm{N}=79\end{array}$ \\
\hline $\begin{array}{l}\text { Systolic BP } \\
(\mathrm{mmHg})\end{array}$ & $112 \pm 13.5$ & $145 \pm 13.2$ & $164.9 \pm 18.5^{*}$ \\
\hline $\begin{array}{l}\text { Diastolic BP } \\
(\mathrm{mmHg})\end{array}$ & $62 \pm 6.9$ & $94 \pm 10.7$ & $112 \pm 11.4^{*}$ \\
\hline $\begin{array}{l}\text { Urine albumin } \\
\text { (mg) }\end{array}$ & $0.2 \pm 0.12$ & $0.3 \pm 0.4$ & $1.5 \pm 0.4 *$ \\
\hline $\begin{array}{l}\text { Hematocrit } \\
(\%)\end{array}$ & $32 \pm 4.2$ & $33.4 \pm 2.0$ & $34.7 \pm 2.6$ \\
\hline $\begin{array}{l}\text { Platelets } \\
(\times 109 / 1)\end{array}$ & $256 \pm 22.7$ & $200 \pm 38.8$ & $179.5 \pm 56$ \\
\hline $\begin{array}{l}\text { Creatinine } \\
(\mathrm{mg} / \mathrm{dl})\end{array}$ & $0.6 \pm 0.2$ & $0.7 \pm 0.5$ & $1.1 \pm 0.6$ \\
\hline Urea (mg/dl) & $9.1 \pm 1.1$ & $15 \pm 6.4$ & $18.4 \pm 5.4$ \\
\hline $\begin{array}{l}\text { Uric acid } \\
(\mathrm{mg} / \mathrm{dl})\end{array}$ & $3.2 \pm 0.5$ & $4.8 \pm 1.9$ & $6.9 \pm 1.3 *$ \\
\hline LDH (IU/l) & $323 \pm 58$ & $478 \pm 86$ & $756 \pm 76^{* * *}$ \\
\hline ALT (IU/l) & $15.8 \pm 2.4$ & $26 \pm 7.3$ & $92.4 \pm 6.8 * *$ \\
\hline AST (IU/l) & $19.3 \pm 5.2$ & $28.2 \pm 7.6$ & $85.2 \pm 7.4 * *$ \\
\hline
\end{tabular}

Table 3: Symptoms according to the level of LDH in preeclampsia.

\begin{tabular}{|llll|}
\hline & $\begin{array}{l}\text { LDH } \\
<600 \text { IU/I } \\
\text { N=32 }\end{array}$ & $\begin{array}{l}\text { LDH } \\
=600-800 \\
\text { IU/l }(\mathbf{N}=29)\end{array}$ & $\begin{array}{l}\text { LDH } \\
>800 ~ I U / 1 \\
\text { N=18 }\end{array}$ \\
\hline $\begin{array}{l}\text { Epigastric } \\
\text { pain }\end{array}$ & $7(21.8)$ & $11(37.93)$ & $14(77.7)^{* * *}$ \\
\hline $\begin{array}{l}\text { Blurred } \\
\text { vision }\end{array}$ & $4(12.5)$ & $8(27.5)$ & $12(66.6) * * *$ \\
\hline Vomiting & $12(37.5)$ & $16(55.17)$ & $15(83.3)^{* * *}$ \\
\hline Headache & $16(50)$ & $26(89.6)$ & $17(89.47)$ \\
\hline
\end{tabular}

Values in parentheses are percentages.

Headache was the most frequent symptom of severe preeclampsia. It was seen in $89.6 \%$ of severe preelampsia patients whose LDH is between 600 to $800 \mathrm{IU} / \mathrm{L}$ and in $89.4 \%$ patients with $\mathrm{LDH}>800 \mathrm{IU} / \mathrm{L}$, followed by vomiting $(55.17 \%)$, epigastric pain $(37.9 \%)$ and blurred vision $(27.5 \%)$. Severely pre-eclamptic women with LDH $>800$ IU/l showed significant increases in terms of eclampsia, abruptio placenta, intracranial hemorrhage, HELLP syndrome, acute renal failure, disseminated intravascular coagulation, and pulmonary edema compared with women who had lower levels $(\mathrm{p}<0.001)$. Eclampsia was the most frequent complication, accounting for $38.8 \%$, followed by abruptio placenta and HELLP syndrome. There were no significant differences between the different subgroups of severe pre-eclampsia according to the levels of $\mathrm{LDH}$ in terms of birth weight and mode of delivery, but patients who had LDH >600 IU/l showed a significant increase in the incidence of perinatal death $(\mathrm{p}<0.001)$.
Table 4: Complications of severe pre-eclampsia according to the level of $\mathrm{LDH}$.

\begin{tabular}{|c|c|c|c|}
\hline & $\begin{array}{l}\text { LDH } \\
<600 \text { IU/I } \\
\mathrm{N}=32\end{array}$ & $\begin{array}{l}\mathrm{LDH}=600- \\
800 \mathrm{IU} / \mathrm{l} \\
\mathrm{N}=29\end{array}$ & $\begin{array}{l}\mathrm{LDH}>\mathbf{8 0 0} \\
\mathrm{IU} / \mathrm{l} \\
\mathbf{N}=\mathbf{1 8}\end{array}$ \\
\hline Eclampsia & 0 & $2(6.8)$ & $7(38.8)$ \\
\hline $\begin{array}{l}\text { Abruptio } \\
\text { placenta }\end{array}$ & 0 & $1(3.4)$ & $4(22.2 \%)$ \\
\hline $\begin{array}{l}\text { Intracranial } \\
\text { hemorrhage }\end{array}$ & 0 & 0 & $1(5.55)$ \\
\hline $\begin{array}{l}\text { HELLP } \\
\text { syndrome }\end{array}$ & 0 & 0 & $2(11.1)$ \\
\hline $\begin{array}{l}\text { Acute renal } \\
\text { failure }\end{array}$ & 0 & 0 & $1(5.55)$ \\
\hline $\begin{array}{l}\text { Pulmonary } \\
\text { edema }\end{array}$ & 0 & 0 & $1(5.55)$ \\
\hline DIC & 0 & $1(3.4)$ & $1(5.55)$ \\
\hline Total & & $4(13.6)$ & $\begin{array}{l}17 \\
(94.3) * * *\end{array}$ \\
\hline
\end{tabular}

Table 5: Pregnancy outcome according to the level of LDH.

\begin{tabular}{|lll|l|}
\hline & $\begin{array}{l}\text { LDH } \\
\text { IU/1 } \\
\text { N=32 }\end{array}$ & $\begin{array}{l}\text { LDH } \\
=600-800 \\
\text { IU/l }(\mathrm{N}=29)\end{array}$ & $\begin{array}{l}\text { LDH } \\
>800 \\
\text { N=18 IU/l }\end{array}$ \\
\hline $\begin{array}{l}\text { Perinatal } \\
\text { death }\end{array}$ & $2(6.25 \%)$ & $6(20.6)$ & $\begin{array}{l}14 \\
(77.77) * * *\end{array}$ \\
\hline $\begin{array}{l}\text { Birth } \\
\text { weight (g) }\end{array}$ & $1835 \pm 756$ & $1782 \pm 729$ & $1642 \pm 287$ \\
\hline $\begin{array}{l}\text { Mode of delivery } \\
\text { NVD* }\end{array}$ & $13(40.6)$ & $12(41.3)$ & $7(38.8)$ \\
\hline $\begin{array}{l}\text { Caesarean } \\
\text { section }\end{array}$ & $19(59.3)$ & $17(58.6))$ & $11(61.1)$ \\
\hline
\end{tabular}

Values in parentheses are percentages.

\section{DISCUSSION}

In the present study majority of the patients belonged to younger age group and were nulliparous. Mean age group in severe preeclampsia is $23.5 \pm 3.3$ and mean parity is $1.1 \pm 0.1$.This finding was also observed by Qublan HS et al. ${ }^{11}$ In present study, we observed a significant rise in the LDH levels with increasing severity of the disease $(\mathrm{P}$ $<0.001$ - statistically significant). Mean LDH level in control is $323 \pm 58$, mean LDH level in mild preeclampsia is $478 \pm 86$ and in severe preeclampsia is $756 \pm 76$. Study by Qublan HS, et al also demonstrated a significant association of serum LDH levels with severe $\operatorname{preeclampsia}(\mathrm{P}<0.001) .{ }^{11}$ In another study by Jaiswar S.P, et al mean LDH levels of control group was $278.3 \pm 119.2$ IU/1 (normotensives). ${ }^{14}$ In mild preeclampsia group it was $400.45+145.21 \mathrm{IU} / 1$ in severe preeclampsia group it was $646.95 \pm 401.64 \mathrm{IU} / \mathrm{l}$ and eclampsia group was $1648.10 \pm 1992.29$ IU/l. In present study, among patients with $\mathrm{LDH}>800$ IU/L, $94.3 \%$ developed complications like eclampsia (38.8\%), abruption (22.2\%), HELLP Syndrome (11.1\%), 
intracranial hemorrhage $(5.5 \%)$, pulmonary edema (5.5\%), acute renal failure $(5.5 \%)$ and DIC (5.5\%) compared to $13.6 \%$ with $\mathrm{LDH} 600-800 \mathrm{IU} / \mathrm{L}$ which is statistically very significant. Statistically significant elevation in renal and liver function is also seen in patients with high LDH in our study. A high serum level of $\mathrm{LDH}(>1,400 \mathrm{IU} / \mathrm{l})$ were shown to have a high predictive value for significant maternal morbidity in a study conducted by Martin JN Jr et al. ${ }^{16}$ Catanzerite VA et $\mathrm{al}^{12}$ reported a subgroup of patients who had elevated levels of LDH manifested with hemolysis, elevated liver enzymes, low platelet count (HELLP) syndrome and were at a high risk for developing maternal mortality. Demir SC et al ${ }^{13}$ concluded that there was a statistically significant relation between maternal complications and high LDH levels. It was noted that in early onset severe preeclampsia, LDH levels before delivery were significantly higher in the abruption group.

Perinatal death was seen in $77.7 \%$ of women with $\mathrm{LDH}>800 \mathrm{IU} / \mathrm{L}$ compared to $20.6 \%$ with $\mathrm{LDH} 600-800$ $\mathrm{IU} / \mathrm{L}$ and $6.25 \%$ in women with $\mathrm{LDH}<600 \mathrm{IU} / \mathrm{L}$ which is statistically very significant $(p<0.001)$. There is reduction in the average weight of babies with higher level of LDH but not statistically significant. This indicates increase in preterm deliveries in patients with higher LDH levels in the present study. This is in accordance with the study done by Umasatyasri $\mathrm{Y}$ et al. ${ }^{15}$ There was no statistical difference in the mode of delivery between case and controls.

\section{CONCLUSION}

Pre-eclampsia is considered an idiopathic multisystem disorder that is specific to pregnancy. A complex of endocrinological mechanisms is believed to be responsible for the multiorgan dysfunction. In order to prevent it, we must diagnose the disease at its earliest. The triad of high blood pressure, oedema and albuminuria is neither specific nor sensitive; therefore the search is on for a reliable marker. In the present study, LDH has been evaluated as a biochemical marker for preeclampsia and as a prognosticator of the disease severity. Detection of high-risk patients with increased levels of LDH mandate close monitoring and management to prevent maternal and fetal morbidity and mortality.

\section{Funding: No funding sources}

Conflict of interest: None declared

Ethical approval: The study was approved by the Institutional Ethics Committee

\section{REFERENCES}

1. Lain KY, Roberts JM. Contemporary concepts of the pathogenesis and management of preeclampsia. JAMA. 2002;287:3183-6.
2. Norwitz ER, Hsu CD, Repke JT. Acute complications of preeclampsia. Clin Obstet Gynecol. 2002;45:308-93.

3. Lim KH, Zhou Y, Janatpour M. Human cytotrophoblast differentiation/invasion is abnormal in preeclampsia. Am J Pathol. 1997;151:1809-18.

4. Var A, Yildirim Y, Onur E. Endothelial dysfunction in preeclampsia:increased homocystine and decreased nitric acid levels. Gynecol Obstet Invest. 2003;56:221-4.

5. Friedman SA, Schiff E, Emeis JJ. Biochemical corroboration of endothelial involvement in severe preeclampsia. Am J Obstet Gynecol. 1995;172:2023.

6. Page NM. The endocrinology of pre-eclampsia. Clin Endocrinol,2002; 57: 413-23

7. Solomon CG, Seely EW. Preeclampsia - Searching for the cause. N Eng J Med. 2004;350:641-42.

8. Peralta Pedrero ML, Basavilvazo Rodriguez MA, Cruz Avelar A. Clinical signifi cance of the laboratory determinations in preeclamptic patients. Ginecol Obstet Mex. 2004;72:57-62.

9. Krefetz RG. Enzymes. Clinical Chemistry, 4th ed. Lippincott Williams and Wilkins; Philadelphia. 2000:196-8.

10. Beyer C: Lactate dehydrogenase isoenzymes in serum of patients with preeclampsia/eclampsia complicated by the HELLP syndrome. Clin Chim Acta. 1991;202:119-20.

11. Qublan HS, Amarun V, Bateinen O. $\mathrm{LDH}$ as biochemical marker of adverse pregnancy outcome in severe preeclampsia Med Sci Monit. 2005;11:3937.

12. Catanzerite VA, Steinberg SM, Mosley CA. Severe preeclampsia with fulminant and extreme elevation of aspartate aminotransferase and lactate dehydrogenase levels. Am J Perinatol. 1995;12:3103.

13. Demir SC, Evruke C, Ozgunen FT. Factors that influence morbidity, and mortality in severe preeclampsia,eclampsia and HELLP syndrome. Saudi Med J. 2006;27:1015-8.

14. Jaiswar SP, Gupta A. Lactic Dehydrogenase: A biochemical markerfor preeclampsia-eclampsia. JOGI. 2011;61(6):645-8.

15. Umasatyasri Y. Role of LDH (Lactate dehydrogenase) in preeclampsia marker: An observational study. IAIM. 2015;2(9).

16. Martin JN Jr, May WL, Magann EF. Early risk assessment of severe preeclampsia: Admission battery of symptoms and laboratory tests to predict likelihood of subsequent significant maternal morbidity. Am J Obstet Gynecol. 1999;180:1407-14.

Cite this article as: Vinitha PM, Chellatamizh M, Padmanaban S. Role of serum LDH in preeclampsia as a prognostic factor - a cross sectional case control study in tertiary care hospital. Int J Reprod Contracept Obstet Gynecol 2017;6:595-8. 